\title{
Reduced adipose tissue triglyceride synthesis and increased muscle fatty acid oxidation in C5L2 knockout mice
}

\author{
Sabina Paglialunga ${ }^{1,2}$, Patrick Schrauwen ${ }^{3}$, Christian Roy ${ }^{2}$, Esther Moonen-Kornips ${ }^{3}$, Huiling Lu ${ }^{2}$, Matthijs \\ K C Hesselink ${ }^{4}$, Yves Deshaies ${ }^{2}$, Denis Richard ${ }^{2}$ and Katherine Cianflone ${ }^{1,2}$ \\ ${ }^{1}$ Department of Biochemistry, McGill University, Montreal, Canada H3G 1V6 \\ ${ }^{2}$ Centre de Recherche de I'Hôpital Laval, Université Laval, Y2186, 2725 Chemin Ste-Foy, Québec, Canada G1V 4G5 \\ ${ }^{3}$ Department of Human Biology, Nutrition and Toxicology Research Institute Maastricht, ${ }^{4}$ Movement Sciences, Maastricht University, Maastricht, 6200 \\ The Netherlands \\ (Requests for offprints should be addressed to K Cianflone; Email: katherine.cianflone@crhl.ulaval.ca)
}

\begin{abstract}
Activation of C5L2, a G-protein-coupled receptor, by acylation-stimulating protein/complement C3adesArg (ASP/C3adesArg) has been shown to stimulate triglyceride (TG) synthesis in both mature adipocytes and preadipocytes. ASP is an adipocyte-derived hormone that acts by increasing diacylglycerol acyltransferase activity and glucose transport. ASP-deficient mice (C3KO, precursor protein) are lean, display delayed postprandial TG clearance, increased food intake, and increased energy expenditure. The present study shows that C5L2KO mice on a low fat diet are hyperphagic ( $\sim 60 \%$ increase in total food intake) yet maintain the same body weight and adipose tissue mass as wild-type (WT) controls. However, on a high fat diet, average adipocyte size and adipose tissue TG/DNA content were significantly reduced and postprandial TG clearance was delayed in C5L2KO. Adipose tissue TG synthesis (WT: $47 \cdot 2 \pm 5 \cdot 6$ versus C5L2KO: $7 \cdot 8 \pm 1 \cdot 8 \mathrm{pmol} / \mu \mathrm{g}$ protein, $P<0 \cdot 001)$, TG lipolysis (WT: $227 \cdot 6 \pm 36 \cdot 4$ versus C5L2KO: $45 \cdot 8 \pm$
\end{abstract}

$5.0 \mathrm{nmol} / \mu \mathrm{g}$ protein, $P<0.001)$, and fatty acid re-esterification (WT: $85 \cdot 3 \pm 2 \cdot 4 \%$ versus C5L2KO: $59 \cdot 5 \pm 6 \cdot 8 \%$, $P<0 \cdot 001)$ were significantly reduced in C5L2KO mice. Indirect calorimetry measurements revealed C5L2KO mice have unchanged oxygen consumption levels yet reduced respiratory quotient value, suggesting preferential fatty acid utilization over carbohydrate. In agreement, fatty acid oxidation was elevated in heart and skeletal muscle tissue in C5L2KO mice and skeletal muscle levels of uncoupling

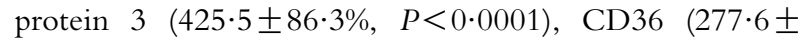
$49 \cdot 5 \%, P<0 \cdot 05)$, cytochrome $c(252 \cdot 6 \pm 33 \cdot 9 \%, P<0 \cdot 05)$, and phospho-acetyl CoA carboxylase $(118 \cdot 4 \pm 9 \cdot 3 \%$, $P<0 \cdot 05)$ were significantly increased in $\mathrm{C} 5 \mathrm{~L} 2 \mathrm{KO}$ mice versus WT $(100 \%)$. The study shows that in response to reduced $\mathrm{TG}$ storage in white adipose tissue, $\mathrm{C} 5 \mathrm{~L} 2 \mathrm{KO}$ mice have developed a compensatory mechanism of increased muscle fat oxidation.

Journal of Endocrinology (2007) 194, 293-304

\section{Introduction}

Adipocyte triglyceride (TG) synthesis is stimulated through activation of the $\mathrm{C} 5 \mathrm{~L} 2$ receptor by its ligand acylationstimulating protein (ASP/C3adesArg). The ASP-C5L2 pathway stimulates TG synthesis (TGS) by increasing diacylglycerol acyltransferase activity, the final enzyme in the TGS cascade (Yasruel et al. 1991, Kalant et al. 2005). In a paracrine and/or autocrine fashion, ASP and its arginated precursor (C3a) increase TGS in both adipocytes and preadipocytes. This has been demonstrated in human- and murine-derived cell lines, and whole tissue (Walsh et al. 1989, Cianflone et al. 1994, 1999). ASP has also been shown to stimulate glucose transport in adipose tissue by increasing glucose transporter 4 (GLUT-4) translocation (Maslowska et al. 1997, Tao et al. 1997) and to inhibit lipolysis, functions which are independent and additive to insulin (van Harmelen et al. 1999). ASP accelerates dietary postprandial TG clearance, as demonstrated in both wild-type (WT) and ASP-deficient mice given a bolus ASP injection during an oral fat load (Murray et al. 1999a, Xia et al. 2004).

C5L2 is a G-protein-coupled receptor highly expressed in fat depots, liver, and spleen (Kalant et al. 2005). It is a serpentine receptor related to the C5aR, C3aR, and fMLP family of chemokine receptors (Ohno et al. 2000). This family of receptors is activated during an immune attack to recruit macrophages and neutrophils to a site of infection; however, it has been shown that C5L2 is not involved in chemotaxis response (Cain \& Monk 2002). C5L2 binds other ligands such as the ASP precursor C3a as well as structurally similar ligands $\mathrm{C} 5 \mathrm{a}$ and $\mathrm{C} 4 \mathrm{a}$ with varying affinities and capacities for crosscompetition. C5a binding to C5L2 in a transfected cell-based assay does not stimulate TGS, and this holds true for cells endogenously expressing C5L2 (Kalant et al. 2003). 
Moreover, ASP and C5a do not compete for the same binding sites on C5L2 (Kalant et al. 2003). A proposed alternate function of C5L2 is to act as a decoy receptor, sequestering $\mathrm{C} 5 \mathrm{a}$ from circulation and preventing $\mathrm{C} 5 \mathrm{a}$ interaction with C5aR (Gao et al. 2005). Gerard et al. (2005) recently demonstrated that $\mathrm{C} 5 \mathrm{~L} 2 \mathrm{KO}$ mice have active $\mathrm{C} 5 \mathrm{aR}$ and are more sensitive to immune attack during injury; however, lipid metabolism was not examined. It should be noted that C3a manifests the same bioactivity as ASP (Kalant et al. 2005); however, physiological C3a is rapidly cleaved by circulating carboxypeptidases to generate ASP. To date, ASP/C3a are the only ligands shown to activate the $\mathrm{C} 5 \mathrm{~L} 2$ receptor.

To evaluate the in vitro functional role of ASP-C5L2, C5L2 was stably transfected and overexpressed in HEK293 cells competent for both TGS and glucose transport. ASP stimulated TGS and glucose transport several fold over basal (Kalant et al. 2005). Following ASP binding, the receptor was phosphorylated and internalized via $\beta$-arrestin translocation (Kalant et al. 2005), a cytosolic protein that targets clathrincoated vesicle formation during endocytosis for receptor desensitization (Claing et al. 2002). By contrast, C5L2 antisense oligos significantly reduced receptor expression, with concordant loss of ASP-stimulated TGS in the murine preadipocyte 3T3-L1 cell line, demonstrating that C5L2 is necessary and sufficient for ASP action (Kalant et al. 2005).

The aim of the present study was to extend the above in vitro findings by examining the physiological consequences of gene knockout $(\mathrm{KO})$ of $\mathrm{C} 5 \mathrm{~L} 2$ and its influence on lipid storage and energy expenditure. C5L2KO mice were characterized based on lipid parameters, muscle metabolism, and adipose tissue TGS.

\section{Materials and Methods}

Mice

C5L2 $(-/+)$ heterozygous mice were obtained from Regeneron Pharmaceutics Inc. courtesy of Dr Joseph Sorrentino (Tarrytown, NY, USA). The methodology for development of these $\mathrm{KO}$ transgenic mice using the technique of VelociGene has been previously described in detail (Valenzuela et al. 2003). Heterozygous breeding in our internal colony generated C5L2KO and WT littermates and mice were selected by PCR genotyping. Briefly, mouse tail clippings were digested overnight and DNA was extracted using DNeasy kit (Qiagen). The PCR included PCR enhancer reagents (Invitrogen) and $25 \mu \mathrm{M}$ each primer. Using the same forward primer: 5'-CTTGTTGGCCCTCTTTCTCC- $3^{\prime}$, the WT gene was detected with WT reverse primer: $5^{\prime}$-GATGGGCACAGCCAGGAAG- $3^{\prime}$ or the $K O$ gene was detected with KO reverse primer: 5'-GTCTGTCCTAGCTTCCTCACTG- $3^{\prime}$. The reaction conditions were 40 cycles at $96{ }^{\circ} \mathrm{C}$ for $30 \mathrm{~s}, 50{ }^{\circ} \mathrm{C}$ for $30 \mathrm{~s}$, and $72{ }^{\circ} \mathrm{C}$ for $30 \mathrm{~s}$. The products were separated by electrophoresis on a $7 \%$ polyacrylamide gel and visualized with silver staining (Bio-Rad).
All mice were housed individually in a sterile barrier facility with $12 \mathrm{~h}$ light: $12 \mathrm{~h}$ darkness at the animal facility. At 9 weeks, mice were placed on low fat (LF) diet $(10 \% \mathrm{kcal}$ fat; Charles River Laboratories, Wilmington, PA, USA) or a high fat-high sucrose (HF/HS) diet (58\% kcal fat; Research Diets Inc., New Brunswick, NJ, USA) and were killed at 21 weeks of age after 12 weeks on diets. All protocols were approved and were conducted in accordance with the CACC guidelines and approved by the University Animal Care Committee.

\section{Chemicals}

$\left[\gamma-{ }^{32} \mathrm{P}\right]$ ATP, $\left[{ }^{3} \mathrm{H}\right]$ palmitate, $\left[{ }^{3} \mathrm{H}\right]$ oleate, $\mathrm{D}-\left[1-{ }^{14} \mathrm{C}\right]$ glucose were obtained from Perkin-Elmer (Perkin-Elmer Life Sciences, Boston, MA, USA), alumina oxide 06300 Fluka for chromatography was from Fluka Chemicals (FlukaRiedel, Buchs, Switzerland), and all other chemicals were from Sigma (Sigma-Aldrich).

\section{Body weight, food intake, and body composition}

Body weight and food intake (15-21 weeks) were measured twice weekly. Body composition to measure total percent body fat was measured by dual-energy X-ray absorptiometry (DEXA) using the PIXIMUS mouse densitometry apparatus (Lunar Corporation, Madison, WI, USA) at 21 weeks of age. Mice were given an i.m. injection for general anesthesia before the scan. Oxygen consumption $\left(\mathrm{VO}_{2}\right)$, carbon dioxide production $\left(\mathrm{VCO}_{2}\right)$, and the respiratory quotient $(\mathrm{RQ})$ were measured over a 48-h period in an open circuit system with the S-3A1 oxygen analyzer (Applied Electrochemistry, Pittsburgh, PA, USA) and the CD-3A carbon dioxide analyzer (Applied Electrochemsitry). $\mathrm{VO}_{2}$ and $\mathrm{VCO}_{2}$ were calculated as $\mathrm{ml} / \mathrm{kg}$ per $\mathrm{h}$ and $\mathrm{RQ}$ was taken as the quotient of $\mathrm{VCO}_{2} / \mathrm{VO}_{2}$.

\section{Plasma assays}

Fasting plasma samples were taken at the time of killing by cardiac puncture. Plasma TGs and non-esterified fatty acids (NEFA) were measured using colorimetric enzymatic kits (Roche Diagnostics and Wako Chemicals, Richmond, VA, USA respectively). Glucose was measured using the Trinder glucose kit (Sigma). Insulin, leptin, and adiponectin were measured using RIA kits (Linco, St Charles, MO, USA).

\section{Adipose tissue histology}

Gonadal tissue was preserved in 4\% paraformaldehyde. Tissue sections were cut $4 \mu \mathrm{m}$ thick and fixed onto slides using standard histological methods. Slides were stained with hematoxylin and eosin (H\&E) dye. Adipocyte volume (50 cells/mouse) was measured using Image-Pro Plus (Media Cybernetics INC, Bethesda, MD, USA) under $20 \times$ magnification (Olympus, Center Valley, PA, USA). 


\section{Adipose tissue TG mass}

TG was extracted from gonadal adipose tissue overnight in $500 \mu$ heptane-isopropanol $(3: 2)$ at $4{ }^{\circ} \mathrm{C}$. TG content was measured using a colorimetric kit as described above. Tissue samples were homogenized with a polytron homogenizer for $20 \mathrm{~s}$ in tissue lysis buffer $\left(50 \mathrm{mM} \mathrm{NaH}{ }_{2} \mathrm{PO}_{4}, 2 \mathrm{M} \mathrm{NaCl}, 2 \mathrm{M}\right.$ EDTA, pH 7-6). Total DNA was measured by a DNA quantification kit (Sigma) and results are presented as moles TG/ $\mu \mathrm{g}$ DNA.

\section{Lipogenesis and lipolysis assay}

Mouse gonadal adipose tissue was collected after killing and placing in room temperature PBS, cut into very small pieces $(10-20 \mu \mathrm{g})$ and placed into a 48-well plate. Fresh tissue pieces rather than isolated adipocytes are commonly used to examine lipogenesis and lipolysis in white adipose tissue (WAT; Faraj \& Cianflone 2004, Festuccia et al. 2006). The tissue was treated with insulin $(100 \mathrm{nM})$, the non-selective $\beta$-agonist isoproterenol $(10 \mu \mathrm{M})$, ASP

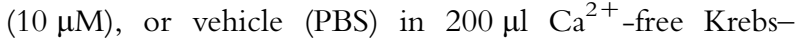
Ringer Buffer (KRB) containing 1\% fatty acid-free BSA, $5 \mathrm{mM}$ glucose, and $\mathrm{D}-\left[1-{ }^{14} \mathrm{C}\right]$ glucose $(1 \mu \mathrm{Ci} / \mu \mathrm{l})$ for $3 \mathrm{~h}$ at $37^{\circ} \mathrm{C}$. The plate was placed on ice to stop the reaction, and the buffer was removed and stored at $-20{ }^{\circ} \mathrm{C}$ for NEFA and glycerol analysis. Tissue lipids were extracted overnight in $500 \mu \mathrm{l}$ heptane-isopropanol $(3: 2)$ at $4{ }^{\circ} \mathrm{C}$. The following day, lipids were re-extracted from the tissue fragments and the two pools were combined and the solvent evaporated. To select for neutral lipids (TGs), alumina was added to each sample $(0.1 \mathrm{~g} / \mathrm{ml})$ to bind phospholipids (Neri \& Frings 1973), mixed for $15 \mathrm{~min}$ at room temperature, centrifuged at $3000 \mathrm{~g}$ for $15 \mathrm{~min}$ at $4{ }^{\circ} \mathrm{C}$ and $500 \mu \mathrm{l}$ supernatant was transferred to a scintillation vial and counted. TG constitutes $85-90 \%$ of the total labeled lipid product (unpublished observation). Soluble protein was extracted and measured as described above. Results are expressed as pmol/ $\mu \mathrm{g}$ protein. NEFA and glycerol released by the tissue into the buffer were measured using colorimetric enzymatic commercial kits described above. Results are expressed as nmol/ $\mu$ g protein. Percent re-esterification was calculated as $100 \times$ ((glycerol release $\times 3$ )-NEFA release)/(glycerol release $\times 3$ ). In a separate experiment, isolated adipocytes were prepared from fresh adipose tissue by collagenase digestion $(1 \mathrm{mg} / \mathrm{ml}$ type II collagenase, $2 \mathrm{mM}$ glucose, and $2 \%$ fatty acid free BSA) for $45 \mathrm{~min}$ at $37^{\circ} \mathrm{C}$ with shaking. Isolated adipocytes were counted with a hemocytometer and $2 \times 10^{4}$ cells per aliquot were used for the TGS assay. Basal TGS was measured in KRB containing $1 \%$ fatty acid-free BSA, $5 \mathrm{mM}$ glucose, $\mathrm{D}-\left[1-{ }^{14} \mathrm{C}\right]$ glucose $(1 \mu \mathrm{Ci} / \mu \mathrm{l})$ and $100 \mu \mathrm{M}$ $\left[{ }^{3} \mathrm{H}\right]$ oleate $(5 \mu \mathrm{Ci} / \mu \mathrm{l})$ for $4 \mathrm{~h}$ at $37^{\circ} \mathrm{C}$ with shaking as previously described by Walsh et al. (1989).
Fat load and glucose tolerance test (GTT)

At 15 weeks of age, following an overnight fast, $300 \mu$ l olive oil (with $100 \mu \mathrm{l}$ air above the oil) was administered by intragastric gavage feeding tube as described previously (Murray et al. 1999a). Blood samples were taken by saphenous vein bleeding at time $0,2,3,4$, and $6 \mathrm{~h}$ after the fat load. GTT was performed on adult mice (5-6 months of age) following an overnight fast. Blood samples were taken at $0,15,30,60$, and $120 \mathrm{~min}$ after an i.p. glucose injection $(2 \mathrm{mg} / \mathrm{g}$ body weight). For both protocols, blood $(40 \mu \mathrm{l})$ was collected in $2 \%$ EDTA, separated by centrifugation at $5000 \boldsymbol{g}$ for $5 \mathrm{~min}$ and stored at $-20{ }^{\circ} \mathrm{C}$ for further analysis.

\section{Fecal analysis}

Total fecal lipids were analyzed as previously described (Murray et al. 2000) to assess intestinal fat absorption. Fecal samples were collected over a $24-\mathrm{h}$ period in a subset of mice on normal LF diet (10\% kcal fat).

\section{Palmitate oxidation and incorporation into TG}

Skeletal muscle (quadriceps), heart, and liver tissues were collected after killing and placed in room temperature PBS. The tissue was cut into small pieces $(10-20 \mathrm{mg})$ and placed into a 48 -well plate. The tissue was treated with $\mathrm{Ca}^{2+}$-free KRB $(200 \mu \mathrm{l})$ containing 1\% BSA, $5 \mathrm{mM}$ glucose, and $1 \mathrm{mM}$ palmitic acid $\left[{ }^{3} \mathrm{H}\right.$ palmitate, $\left.5 \mu \mathrm{Ci} / \mu \mathrm{l}\right]$ for $2 \mathrm{~h}$ at $37^{\circ} \mathrm{C}$. A Folch extraction was performed with the addition of $2.5 \mathrm{ml}$ chloroform/methanol (2:1) and $1 \mathrm{ml} \mathrm{KCl}: \mathrm{HCl}$ to separate the organic from the aqueous phase. The mixture was vortexed then centrifuged at $3000 \boldsymbol{g}$ for $5 \mathrm{~min}$ and an aliquot of the aqueous phase containing the oxidative product ${ }^{3} \mathrm{H}_{2} \mathrm{O}$, was taken for scintillation counting as previously described (Ibrahimi et al. 1999, Abu-Elheiga et al. 2003). The organic phase, containing ${ }^{3} \mathrm{H}-\mathrm{TG}$, was separated by thin layer chromatography (TLC) and processed as described elsewhere (Kalant et al. 2005). Soluble protein was extracted overnight from the remaining tissue with $500 \mu \mathrm{l}$ of $0.3 \mathrm{M} \mathrm{NaOH}$. The samples were diluted with water to yield a final concentration of $0 \cdot 1 \mathrm{M} \mathrm{NaOH}$ and protein levels were determined using the Bradford assay (Bio-Rad).

\section{Western blot}

Total protein was homogenized from frozen skeletal muscle (quadriceps muscle) samples with lysis buffer (1 mM EDTA, $0.4 \mathrm{mM}$ phenylmethylsulfonyl fluoride in PBS), SDS gel sample buffer was added and protein extracts were separated on a $12 \%$ acrylamide/bis gel (10 and $7 \cdot 5 \%$ gel for assaying GLUT-4 and acetyl CoA carboxylase (ACC) respectively) at $200 \mathrm{~V}$ for $45 \mathrm{~min}$. The proteins were transferred to nitrocellulose via electroblotting $(60 \mathrm{~min}$ at $100 \mathrm{~V})$. Standard blocking and incubation procedures were followed. Primary antibodies used were rabbit anti-mouse 
cytochrome $c$ (BD Pharmingen Tech, San Jose, CA, USA) and uncoupling protein 3 (UCP3; in-house) antibodies, which were followed by peroxide-conjugated swine antirabbit immunoglobulin secondary antibody (Dako, Glostrup, Denmark). Primary anti-murine CD36 (clone 36) antibody (Cascade Bioscience, Winchester, MA, USA) was followed by goat anti-mouse IgA HRP antibody (Southern Biotechnology Ass., Birmingham, AL, USA). After incubation, blots were rinsed in PBS, visualized with West Dura Extended Duration Substrate and exposed on CL-Xposure film (Pierce Biotechnology Inc., Rockford, IL, USA) and analyzed by computer-assisted photodocumentation system. GLUT-4 was visualized using the Odyssey (LI-COR Biotechnology, Lincoln, NE, USA) imaging system. Primary antibody GLUT-4 (in house) and secondary donkey anti-rabbit IR 800 antibodies were used for detection. Phosphorylated ACC was detected using primary anti-phospho-ACC (Ser79) antibody rabbit polyclonal IgG (Upstate, Lake Placid, NY, USA) and secondary goat-anti-rabbit HRP-conjugated antibody. Phosphorylation levels were visualized with enhanced chemiluminescent (ECL) western blotting detection (GE Healthcare, Buckinghamshire, UK) using UVP (Upland, CA, USA) photodocumentation system.

\section{AMP-activated protein kinase (AMPK) activity assay}

AMPK activity was measured as previously described by Sambandam et al. (2004). Briefly, $20 \mathrm{mg}$ frozen tissue (quadriceps muscle) was homogenized in $200 \mu$ l homogenization buffer $\left(50 \mathrm{mM}\right.$ Tris- $\mathrm{HCl}(\mathrm{pH} 8)$ at $4{ }^{\circ} \mathrm{C}, 1 \mathrm{mM}$ EDTA, $10 \%(\mathrm{wt} / \mathrm{v})$ glycerol, 0.02\% (v/v) Brij-35, $1 \mathrm{mM}$ dithiothreitol) containing protease and phosphatase inhibitors. Protein homogenates were centrifuged at $10000 \boldsymbol{g}$ for $20 \mathrm{~min}$ at $4{ }^{\circ} \mathrm{C}$ and protein content was measured by the Bradford assay (Bio-Rad). AMPK activity was determined by the incorporation of $\left[\gamma-{ }^{32} \mathrm{P}\right] \mathrm{ATP}$ into a synthetic peptide, AMARA (Upstate). The assay was performed in a total volume of $25 \mu \mathrm{l}$ containing $80 \mathrm{mM}$ HEPES-NaOH (pH 7.0), $160 \mathrm{mM} \mathrm{NaCl}, 1.6 \mathrm{mM}$ EDTA, $1 \mathrm{mM} \mathrm{MgCl} 2,16 \%$ glycerol, $200 \mu \mathrm{M}$ AMARA peptide, $2 \mathrm{mM}\left[\gamma-{ }^{32} \mathrm{P}\right]$ ATP $(400-600 \mathrm{dpm} / \mathrm{pmol})$, and $5 \mu \mathrm{l}$ protein homogenate. The reaction was performed in both the absence and presence of AMARA at $30^{\circ} \mathrm{C}$ for $15 \mathrm{~min}$ (AMPK-specific phosphorylation activity). The reaction was stopped with the addition of $3 \% \mathrm{H}_{3} \mathrm{PO}_{4}$ then $10 \mu \mathrm{l}$ aliquots of reaction solution were removed and spotted on P81 phosphocellulose paper (Whatman, Florham Park, NJ, USA). The papers were washed, dried, and placed in vials containing $5 \mathrm{ml}$ scintillation fluid. Radioactivity was determined using standard liquid scintillation procedures.

\section{Statistical analyses}

Results are presented as mean \pm s.E.M. In all cases, there was no difference between male and female mice, and results were pooled. Groups were compared by $t$-tests, one- or two-way ANOVA followed by Bonferroni post hoc test or Wilcoxon signed rank test as indicated. Statistical significance was set at $P<0 \cdot 05$, where ns indicates not significant.

\section{Results}

C5L2KO mice on LF diet display increased food intake relative to weight gain

Male and female WT and C5L2KO mice were placed on LF or HF/HS diets for 12 weeks. Over the course of this study no body weight differences were observed between WT and C5L2KO mice on either LF or HF/HS diets (Fig. 1A). However, relative to body weight gain, the C5L2KO-LF mice had almost a two-fold increase in cumulative food intake when compared with WT mice (WT-LF: $511 \cdot 4 \pm 2 \cdot 2 \mathrm{~kJ}$ versus C5L2KO-LF: $821 \pm 37 \cdot 4 \mathrm{~kJ}, P<0 \cdot 0001, n=4$ per group), resulting in a concomitant decrease in food efficiency
A

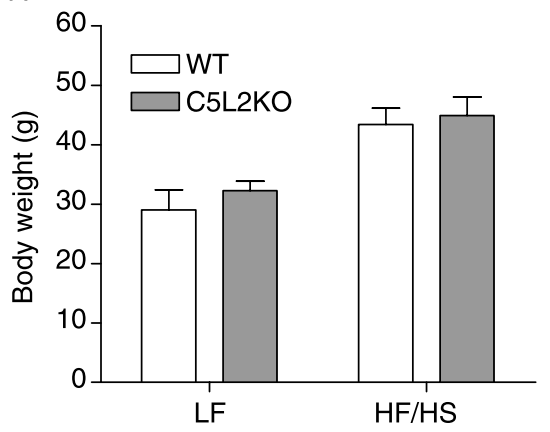

B

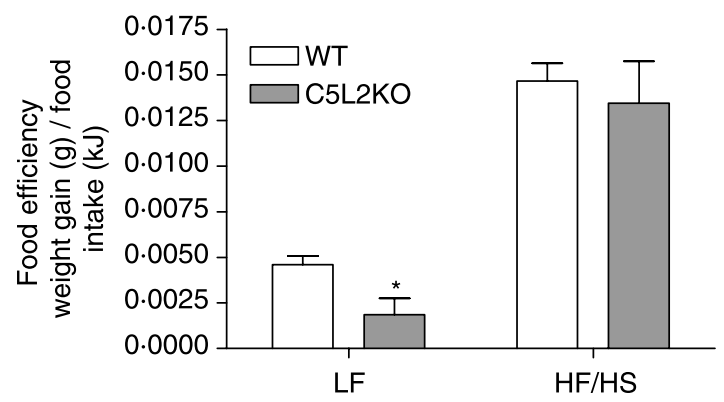

Figure 1 Body weight and food efficiency. Mouse body weight at 21 weeks for WT (white bars) and C5L2KO (grey bars) mice on a LF and HF/HS diet (A). Food efficiency over a 6-week period (15-21 weeks) (B). Food efficiency is calculated as average weight gain (g)/food intake (kJ) for WT (white bars) and C5L2KO (grey bars), $n=4-6$ mice. Values are presented as mean \pm S.E.M. where ${ }^{*} P<0 \cdot 05$ denotes significant differences between WT and C5L2KO evaluated by t-test. 
as shown by the ratio of weight gain/food intake (Fig. 1B). Food intake and food efficiency results for WT-HF/HS and C5L2KO-HF/HS mice were similar to each other, but substantially different from LF diet (Fig. 1B).

\section{Adiposity and adipose tissue analysis}

C5L2KO-LF mice showed no significant difference in either total percent body fat when compared with WT-LF mice measured by DEXA (WT-LF: $21 \cdot 6 \pm 4 \cdot 3 \%$ and C5L2KO-LF: $23 \cdot 4 \pm 2 \cdot 4 \%$ body fat, ns, $n=4$ per group) or gonadal adipose tissue weight (WT-LF: $0 \cdot 76 \pm 0 \cdot 26 \mathrm{~g}$ and C5L2KO-LF: $0 \cdot 80 \pm 0 \cdot 15 \mathrm{~g}$, ns, $n=4$ per group). Furthermore, histological analysis revealed similar adipocyte cell size and TG content between the two groups (Fig. 2). On the HF diet, the total percent body fat of each mouse strain almost doubled when compared with LF counterparts. Again there were no differences between $\mathrm{WT}$ and C5L2KO mice for percent

A

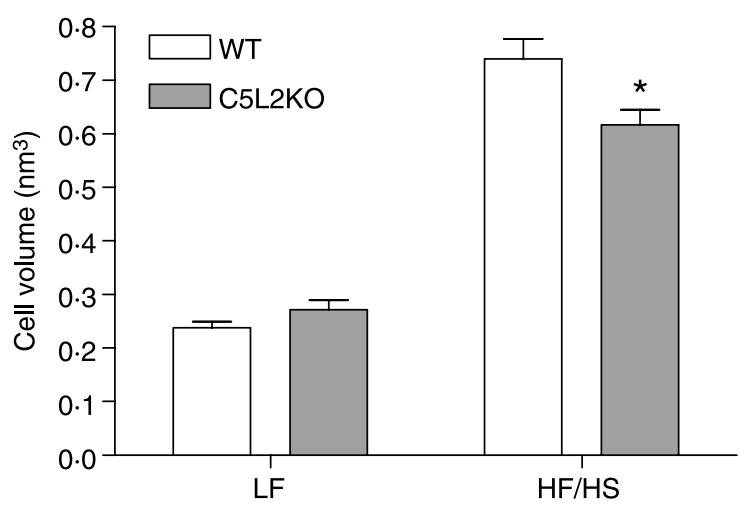

C

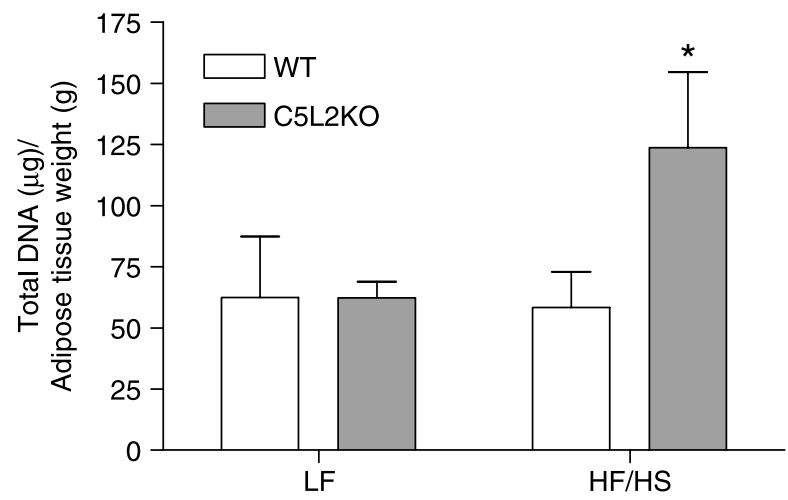

body fat (WT + HF/HS: $46 \cdot 2 \pm 1 \cdot 1 \%$ and C5L2KO + HF/ HS: $44 \cdot 2 \pm 1 \cdot 8 \%$, ns, $n=6$ per group) or for gonadal tissue depot weight (WT-HF/HS: $2 \cdot 63 \pm 0.33 \mathrm{~g}$, and C5L2KO$\mathrm{HF} / \mathrm{HS}: 1.93 \pm 0.22 \mathrm{~g}$, ns, $n=6$ per group). However, C5L2KO-HF/HS mouse adipose tissue was composed of significantly smaller adipocytes (Fig. 2A and B). Total DNA per adipose tissue weight was increased (Fig. 2C) and adipose tissue TG content per unit DNA was also substantially reduced in C5L2KO-HF/HS when compared with WT-HF/ HS mice (Fig. 2D).

\section{C5L2KO mice have reduced adipose tissue TGS}

Gonadal adipose tissue samples were incubated ex vivo to evaluate basal TGS. Basal TGS was markedly decreased in C5L2KO-LF mice when compared with WT-LF mice (Fig. 3A, $P<0 \cdot 001$ ). As intact adipose tissue pieces preserve the microenvironment, local ASP production in adipose

B
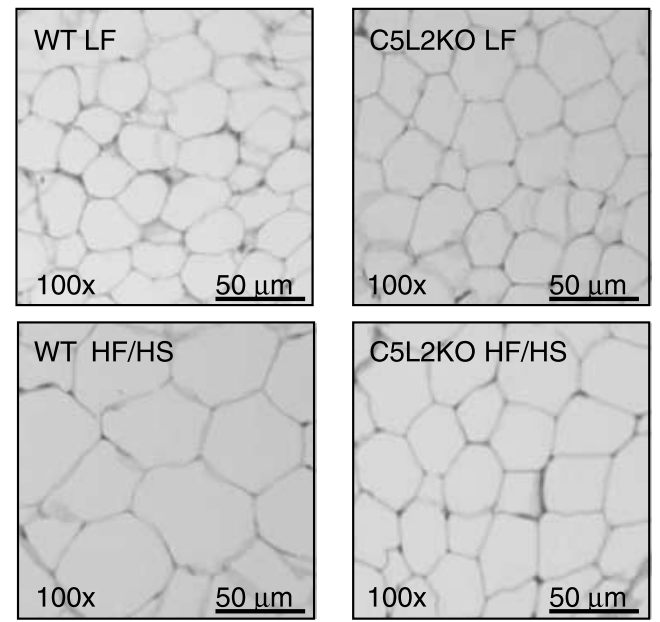

D

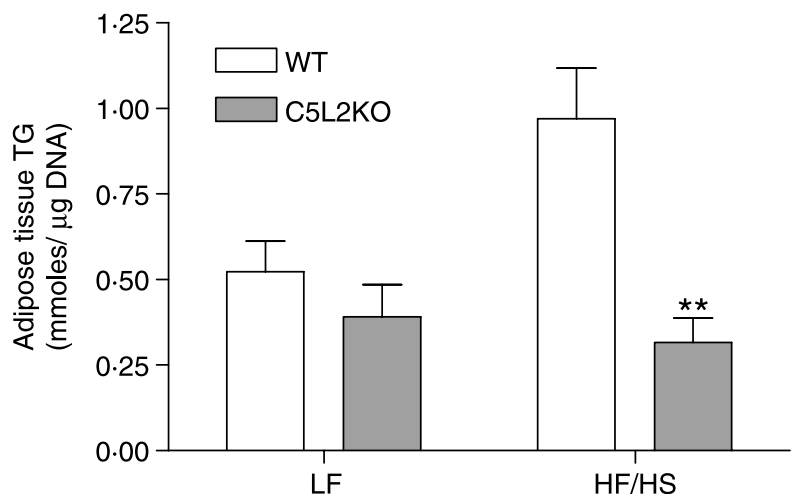

Figure 2 Adipose tissue analysis. Average adipocyte cell volume $\left(\mathrm{nm}^{3}\right)$ for WT (white bars) and C5L2KO (grey bars), where 50 cells/mouse were measured (A). Representative adipose tissue sections where slides were stained with H\&E and viewed at $100 \times$ magnification (B). Adipose tissue total DNA per adipose tissue weight $(\mu \mathrm{g} / \mathrm{g})(\mathrm{C})$. Adipose tissue TG mass (mmols/ $\mu \mathrm{g}$ DNA) (D). Values are presented as mean \pm S.E.M. for $n=4-6$ mice, where $* P<0.05$ and ${ }^{* *} P<0.001$ denote significant differences between WT and C5L2KO as determined by $t$-test. 
A

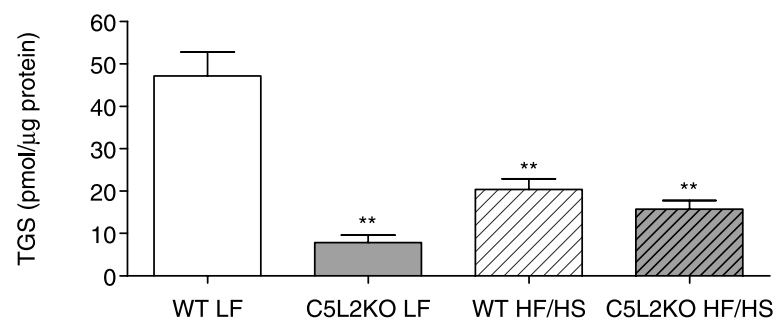

B

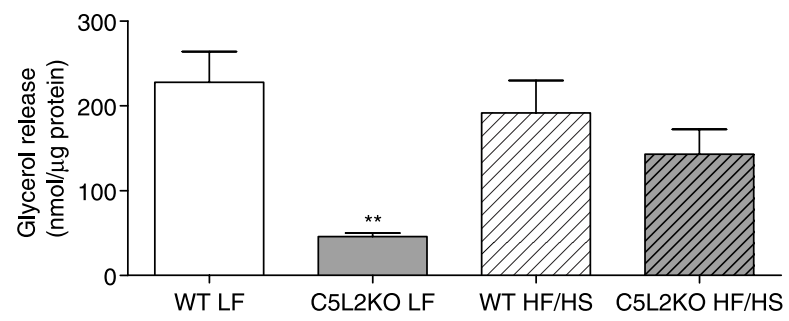

C

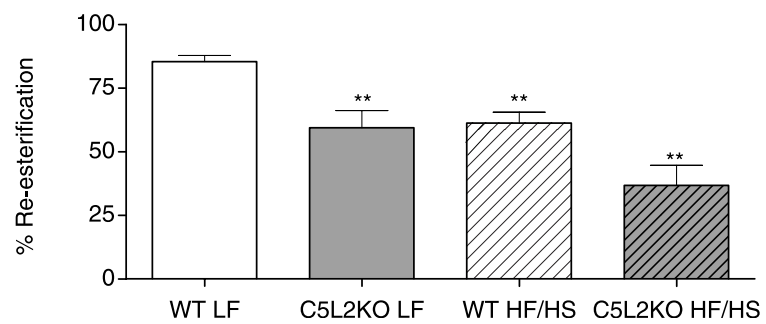

Figure 3 Basal triglyceride synthesis, lipolysis, and fatty acid re-esterification in adipose tissue. Basal triglyceride synthesis (TGS) was measured as D- $\left[1-{ }^{14} \mathrm{C}\right]$ glucose incorporation into TG expressed as $\mathrm{pmol} / \mu \mathrm{g}$ protein (A). Basal TG lipolysis was measured as glycerol release into media expressed as nmol/ $\mu$ g protein (B). Basal \% fatty acid re-esterification calculated as described in Methods (C). Results are presented as mean \pm S.E.M. for WT LF $n=6$ (white bars), C5L2KO LF $n=9$ (grey bars), WT HF/HS $n=6$ (white hatched bars), and C5L2KO $n=9$ (grey hatched bars) samples, where ${ }^{* *} P<0 \cdot 001$ indicates significant differences from WT LF as determined by one-way ANOVA.

tissue from WT mice will act upon the C5L2 receptors in proximity to stimulate TGS, while the adipose tissue from C5L2KO mice will not benefit from this activity due to the absence of C5L2 receptors. Accordingly, isolated adipocytes were prepared from gonadal adipose tissue from a younger subset of mice (10 weeks) and assayed for basal TGS in the absence of ASP. Under these conditions, there was no difference in basal TGS between WT and C5L2KO mice $\left(15 \cdot 5 \pm 6 \cdot 8 \mathrm{pmol} / 2 \times 10^{4}\right.$ cells, $n=15$ samples versus $12 \cdot 8 \pm$ $2 \cdot 5 \mathrm{pmol} / 2 \times 10^{4}$ cells, $n=12$ samples respectively, $\mathrm{ns}$ ). Meanwhile, paired tissue pieces prepared and assayed simultaneously maintained the differences noted between WT and C5L2KO mice $(12 \cdot 7 \pm 4 \cdot 0 \mathrm{pmol} / \mathrm{mg}, n=15$ and $6 \cdot 3 \pm 1 \cdot 6 \mathrm{pmol} / \mathrm{mg}, n=12$ respectively, $P=0 \cdot 0584)$. Table 1 outlines the effect of direct stimulation by insulin or ASP on TGS. Insulin-stimulated TGS up to $251 \pm 16 \%$ in WT mice on LF diet, whereas ASP stimulation increased TGS by $145 \pm 17 \%$ (both $P<0 \cdot 05$ when compared with no stimulation). By contrast, there was no stimulatory effect by ASP on $\mathrm{C} 5 \mathrm{~L} 2 \mathrm{KO}$ adipose tissue, providing further evidence that C5L2 is the ASP receptor for TGS. Interestingly, the response to insulin was also reduced in C5L2KO mice when compared with WT mice, suggesting an altered insulin response in adipose tissue. In the present study, after chronic HF feeding (12 weeks), obese WT-HF/ HS mice demonstrated a decreased basal TGS when compared with WT-LF mice (Fig. 3A). A similar reduction in basal TGS was seen in the C5L2KO-HF/HS diet mice. Nonetheless, in spite of the HF/HS diet, both insulin- and ASP-stimulated TGS in WT adipose tissue, with no stimulation in C5L2KO tissue (Table 1).

Lipolysis, measured as basal glycerol release, is shown in Fig. 3B. Overall, adipose tissue from C5L2KO-LF mice had an $\sim 80 \%$ reduction in glycerol release when compared with WT-LF. Basal lipolysis in WT-HF/HS mice and in C5L2KO$\mathrm{HF} / \mathrm{HS}$ mice was not significantly different from WT-LF mice. $\beta$-Agonist isoproterenol significantly stimulated glycerol release in all groups (Table 2) to the same extent as assessed by one-way ANOVA (ns, Table 2).

Fatty acids released by adipose tissue into the media can be taken back up by the adipocytes and re-esterified to generate TG. A $100 \%$ re-esterification indicates that all of the released fatty acids are taken back up by adipose tissue to form TG. A decrease in re-esterification implies a lower capacity of fatty acid re-uptake and storage. As with TGS and lipolysis, C5L2KO-LF adipose tissue displayed reduced basal re-esterification relative to WT-LF $(P<0 \cdot 001$, Fig. 3C). While the $\mathrm{HF} / \mathrm{HS}$ diet also reduced re-esterification in WT-HF/HS

Table 1 Hormone effect on triglyceride synthesis in adipose tissue. Values are presented as mean \pm S.E.M.

PBS

Mice
WT LF; $n=6$
C5L2KO LF; $n=9$
WT HF/HS; $n=6$
C5L2KO HF/HS; $n=9$

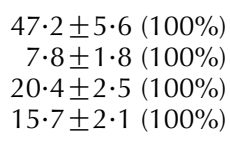

Insulin

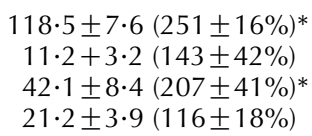

ASP

$$
\begin{gathered}
68 \cdot 4 \pm 8 \cdot 0(145 \pm 17 \%)^{*} \\
5 \cdot 5 \pm 2 \cdot 4(43 \pm 17 \%) \\
28 \cdot 49 \pm 4 \cdot 62(140 \pm 23 \%) \\
16 \cdot 3 \pm 2 \cdot 6(100 \pm 12 \%)
\end{gathered}
$$

Triglyceride synthesis (TGS) was measured as pmol/ $\mu$ g protein. Values in parentheses represent percent stimulation where basal (PBS) TGS was set to $100 \%$. *indicates $P<0 \cdot 05$ compared to PBS, analyzed by Wilcoxon Signed Rank Test. 
Table 2 Isoproterenol effect on glycerol release in adipose tissue. Values are presented as mean \pm S.E.M.

$$
\text { PBS }
$$

$\begin{array}{lc}\text { Mice } & \\ \text { WT LF; } n=6 & 227 \cdot 6 \pm 36 \cdot 4 \\ & (100 \%) \\ \text { C5L2KO LF; } n=9 & 45 \cdot 8 \pm 5 \cdot 0 \\ & (100 \%) \\ \text { WT HF/HS; } n=6 & 191 \cdot 5 \pm 38 \cdot 5 \\ & (100 \%) \\ \text { C5L2KO HF/HS; } n=9 & 142 \cdot 9 \pm 29 \cdot 5\end{array}$$$
(100 \%)
$$

Isoproterenol

$665 \cdot 4 \pm 70 \cdot 5$ $(292 \pm 31 \%)^{*}$ $82 \cdot 5 \pm 12 \cdot 7$

$(180 \pm 28 \%)^{*}$ $349 \cdot 0 \pm 59 \cdot 8$

$(182 \pm 31 \%)^{*}$ $351 \cdot 4 \pm 35 \cdot 8$

$(246 \pm 25 \%)^{*}$
Glycerol release measured as $\mathrm{nmol} / \mu \mathrm{g}$ protein. Results in parentheses indicate percent stimulation where basal (PBS) glycerol release was set to $100 \%$.* indicates $P<0.05$ compared to PBS analyzed by Wilcoxon Signed Rank Test.

mice, C5L2KO-HF/HS mice had an even greater reduction when compared with WT cohorts $(P<0 \cdot 001)$.

\section{C5L2KO mice have delayed postprandial dietary TG clearance}

Fasting lipid and hormone values are presented in Table 3. While there were no significant differences among the LF mice, fasting TG, leptin, and insulin were increased in C5L2KO-HF/HS when compared with WT-HF/HS. Based on the function of the ASP-C5L2 pathway, postprandial fat clearance was evaluated (Fig. 4). C5L2KO-LF diet mice tended to have delayed TG clearance when compared with WT-LF diet mice $(P=0 \cdot 08$, Fig. $4 \mathrm{~A}$ and $\mathrm{C})$. HF/HS diet resulted in increased postprandial lipemia in both WT and C5L2KO mice (diet effect $P<0.0001$ by two-way RM ANOVA). The delay in TG clearance observed in C5L2KOLF mice was significantly amplified by the HF/HS diet $(P<0 \cdot 05$, Fig. 4B and C). Nonetheless, the circulating TG levels still returned to fasting values by the $4-\mathrm{h}$ time point. No significant genotype-related differences were observed during the postprandial increase in NEFA levels for LF mice (area under the curve (AUC) WT-LF: $3 \cdot 85 \pm 0 \cdot 34 \mathrm{mmol} / \mathrm{l}^{\star} \mathrm{h}$ and AUC C5L2KO-LF: $3 \cdot 67 \pm 0 \cdot 34 \mathrm{mmol} /{ }^{\star} \mathrm{h}, \mathrm{ns}, n=4$ per group) and $\mathrm{HF} / \mathrm{HS}$ diet mice (AUC WT-HF/HS: $8 \cdot 22 \pm 0.54 \mathrm{mmol} /{ }^{\star} \mathrm{h}$ and AUC C5L2KO-HF/HS: $8.67 \pm$ $1.00 \mathrm{mmol} / \mathrm{l}^{\star} \mathrm{h}, \mathrm{ns}, n=6$ per group). Intestinal lipid absorption was analyzed by measuring percent total fecal lipids/stool weight; no differences were observed between WT $(1 \cdot 67 \pm 0 \cdot 38 \%, n=3)$ and C5L2KO mice $(0 \cdot 98 \pm 0 \cdot 08 \%$, $n=5, \mathrm{~ns})$, indicating that differences in TG clearance rates are not due to intestinal lipid malabsorption.

\section{C5L2KO mice have altered glucose metabolism}

The GTT revealed that C5L2KO mice had delayed glucose clearance (Fig. 5). Although insulin levels during the GTT were not different among the LF mice, on the HF/HS diet insulin AUC was twofold greater in C5L2KO-HF/HS mice. Despite this significant delay in glucose clearance, fasting glucose levels were similar between WT and C5L2KO mice (Table 3) with no change in skeletal muscle GLUT-4 protein levels as assessed by western analysis (data not shown).

\section{Evaluation of fatty acid oxidation}

The increased food intake despite similar weight gain in C5L2KO-LF mice suggests increased energy expenditure. This possibility was tested by whole body indirect calorimetry. $\mathrm{VO}_{2}$ was not significantly different between WT and C5L2KO mice (Fig. 6A). Figure 6B and C indicates that C5L2KO-LF mice had a significantly lower RQ value when compared with WT-LF mice throughout the day, suggesting preferential oxidation of fatty acids over carbohydrates. As muscle is a major contributor to whole body substrate metabolism, we examined if C5L2KOLF mice had increased muscle fatty acid oxidative capacity (Fig. 7A). Indeed, ex vivo tissue palmitate oxidation was significantly increased in cardiac muscle $(P<0 \cdot 05)$ with a smaller increase in skeletal muscle $(P=0.056)$, while palmitate oxidation in the liver was reduced $(P<0 \cdot 05)$. At the same time, palmitate incorporation into TG in both heart and liver were significantly elevated in C5L2KO mice, with no change in skeletal muscle TGS (Fig. 7B).

Table 3 Fasting plasma lipid and hormone levels. Values are presented as mean \pm S.E.M.

\begin{tabular}{|c|c|c|c|}
\hline $\mathbf{W T} \mathbf{L F}(n=10)$ & C5L2KO LF $(n=12)$ & WT HF/HS $(n=13)$ & C5L2KO HF/HS \\
\hline $0 \cdot 81 \pm 0 \cdot 11$ & $1 \cdot 00 \pm 0 \cdot 13$ & $0 \cdot 71 \pm 0.09$ & $1 \cdot 24 \pm 0 \cdot 09^{* *}$ \\
\hline $0.96 \pm 0.07$ & $0 \cdot 85 \pm 0 \cdot 10$ & $0.91 \pm 0.11$ & $0.97 \pm 0.07$ \\
\hline $8 \cdot 81 \pm 1 \cdot 70$ & $9 \cdot 07 \pm 1 \cdot 28$ & $25 \cdot 80 \pm 7 \cdot 91$ & $60 \cdot 38 \pm 13 \cdot 08^{*}$ \\
\hline $27 \cdot 02 \pm 4 \cdot 53$ & $19 \cdot 04 \pm 2 \cdot 97$ & $8 \cdot 99 \pm 1 \cdot 15$ & $9 \cdot 48 \pm 1 \cdot 64$ \\
\hline $0 \cdot 29 \pm 0 \cdot 11$ & $0 \cdot 30 \pm 0 \cdot 08$ & $0.63 \pm 0.19$ & $1 \cdot 37 \pm 0 \cdot 27^{*}$ \\
\hline $7 \cdot 32 \pm 0.73$ & $6 \cdot 99 \pm 0.72$ & $7 \cdot 96 \pm 0.59$ & $7 \cdot 48 \pm 1 \cdot 07$ \\
\hline
\end{tabular}

Fasting plasma TG, NEFA, leptin, adiponectin, insulin and glucose levels. WT and C5L2KO on each diet were compared by $t$-test where $* P<0 \cdot 05$ and $* * P<0 \cdot 001$. 
A
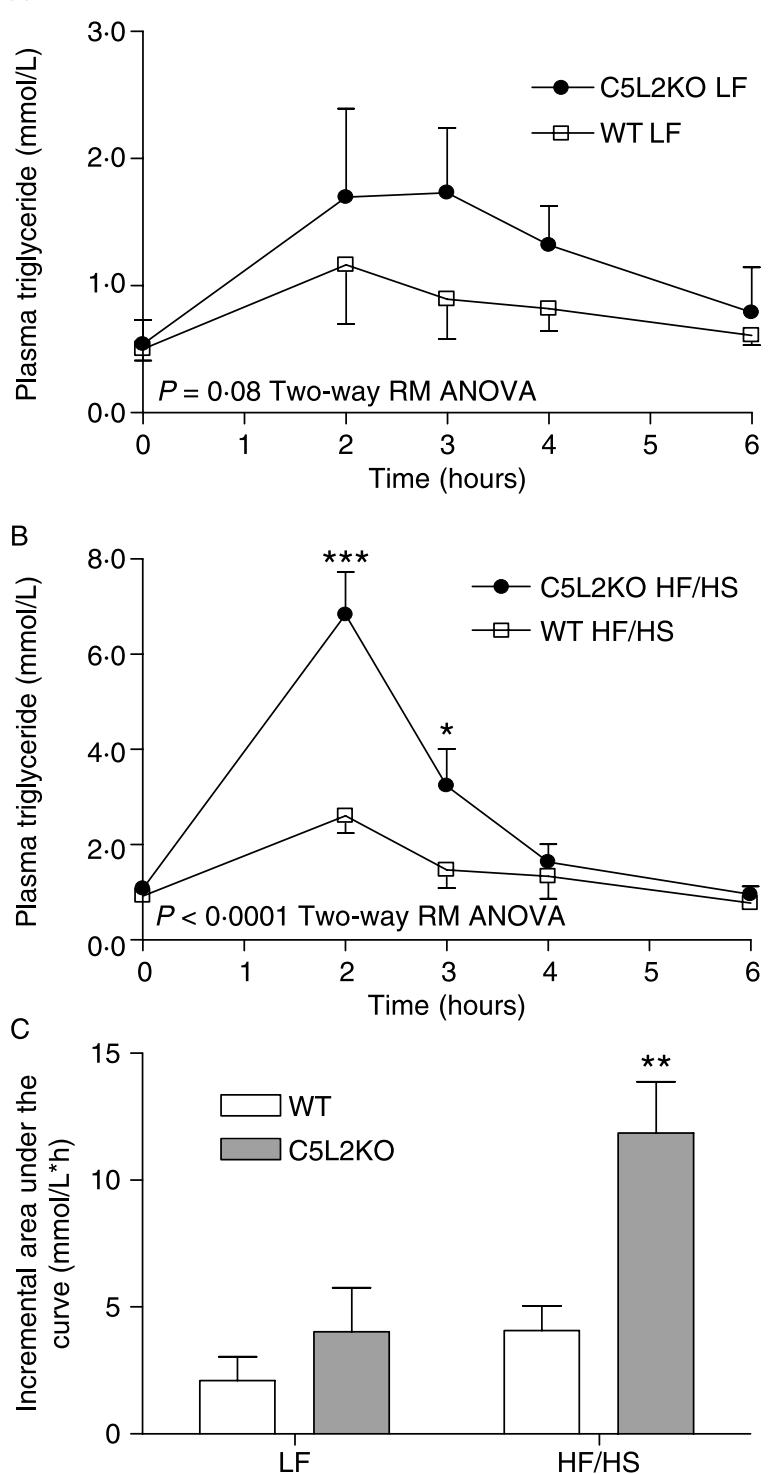

Figure 4 Postprandial dietary fat load clearance. Plasma triglyceride ( $\mathrm{mmol} / \mathrm{l})$ in WT mice (squares) and C5L2KO mice (circles) on low fat (LF) diet (A) and high fat/high sucrose (HF/HS) diet (B), over $6 \mathrm{~h}$ after fatload. Statistical differences were determined by two-way RM-ANOVA with Bonferroni post hoc test. Incremental area-undercurve $(\mathrm{mmol} / \mathrm{l} \times \mathrm{h})$ of TG clearance curves from WT (white bars) and C5L2KO (grey bars) for $n=4-6$ mice are shown in (C). Statistical differences determined by $t$-test. Values are presented as mean \pm S.E.M., where $* P<0 \cdot 05,{ }^{* *} P<0 \cdot 01, * * * P<0 \cdot 0001$.

\section{Alterations in skeletal muscle energy metabolism markers}

Skeletal muscle western blot analysis showed a significant increase in cytochrome $c, \mathrm{CD} 36$, and UCP3 levels in C5L2KO-LF mice versus WT-LF mice (Fig. 7C and D). Increased content of these proteins is consistent with the observed increased capacity for energy formation and fat utilization within muscle. Furthermore, ACC phosphorylation was elevated in C5L2KO-LF mice (Fig. 7E and D), although it was not associated with augmented AMPK activity (Fig. 7F). However, there was a striking twofold increase in AMPK activity in C5L2KO-HF/HS skeletal muscle when compared with WT-HF/HS $(P<0 \cdot 0001)$.

\section{Discussion}

On a LF diet, the prominent features of the C5L2KO mice include i) increased food intake and reduced food efficiency; ii) a small delay in postprandial TG clearance with markedly decreased capacity for adipose tissue TG storage and re-esterification; and iii) preferential fatty acid oxidation as indicated by reduced RQ value, increased ex vivo muscle fatty acid oxidation, and increased expression of proteins involved in skeletal muscle energy metabolism. Of note, the alterations in food intake and fatty acid oxidation occurred without a detectable increase in $\mathrm{VO}_{2}$; other indicators of energy expenditure such as physical activity and heat production, as previously demonstrated in ASP-deficient C3KO mice (Xia et al. 2002, 2004), were not determined. Nonetheless, the compensatory increase in fatty acid oxidation is likely consequent to a decreased capacity for TGS and fatty acid re-esterification.

A normal chow mouse diet contains relatively little dietary fat; therefore, a large majority of adipose tissue fat is derived from de novo synthesis. On a HF/HS diet, with increased fat available from the diet, the de novo fatty acid synthesis pathway is downregulated. Challenging mice with a $\mathrm{HF} / \mathrm{HS}$ diet masked some differences in $\mathrm{C} 5 \mathrm{~L} 2 \mathrm{KO}$ mice otherwise observed with LF diet and emphasized other differences. For example, the HF/HS diet increased food efficiency in both the WT and C5L2KO mice relative to LF, masking a strong genotype difference seen with the latter. Furthermore, the differences between C5L2KO and WT in skeletal muscle protein content (cytochrome $c, \mathrm{CD} 36, \mathrm{UCP} 3$ ) were less marked on $\mathrm{HF} / \mathrm{HS}$, but there was a marked increase in AMPK activity in C5L2KO relative to WT. Similarly, HF/HS downregulated adipose tissue basal TGS which masked the decrease in C5L2KO mice, while in contrast, adipocyte size, adipose tissue TG/DNA, and delayed postprandial plasma TG clearance in C5L2KO mice were strikingly exaggerated, and fatty acid re-esterification was further suppressed.

We have previously investigated the role of the ASP-C5L2 pathway using ASP-deficient C3KO mice (Murray et al. 1999a,b, 2000, Xia et al. 2004). While not all studies agree with our results (Wetsel et al. 1999), Pekna et al. (1998) independently derived a $\mathrm{C} 3 \mathrm{KO}$ mouse colony, demonstrating that $\mathrm{C} 3 \mathrm{KO}$ mice on an atherogenic background (ApoE and low density lipoprotein (LDL) receptor $\mathrm{KO}$ mice) were characterized by substantially decreased adipose tissue and altered plasma lipoprotein profile (Persson et al. 2004). In agreement, we have previously shown $\mathrm{C} 3 \mathrm{KO}$ mice are lean, and as a consequence are resistant to obesity even on a HF diet 

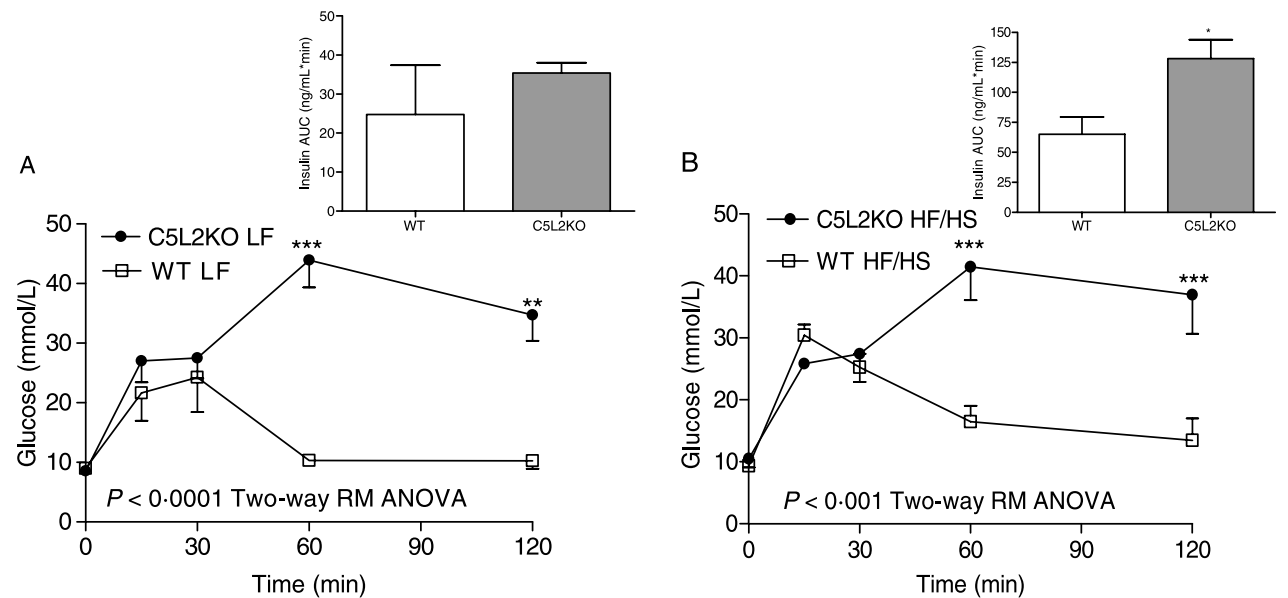

Figure 5 Glucose tolerance test. Plasma glucose ( $\mathrm{mmol} / \mathrm{l})$ levels over $120 \mathrm{~min}$ after i.p. glucose injection in WT mice (squares) and C5L2KO mice (circles) on low fat (LF) diet (A) and high fat/high sucrose (HF/HS) diet (B). Insert: insulin incremental area-under-curve $(\mathrm{ng} / \mathrm{l} \times \mathrm{min})$ during glucose tolerance test for WT (white bars) and C5L2KO (grey bars) for $n=6-7$ mice. Statistical differences were determined by RM- ANOVA (glucose) followed by Bonferroni post hoc test and $t$-test (insulin). Values are presented as mean \pm s.E.M., where $* P<0 \cdot 05, * * P<0 \cdot 01, * * * P<0 \cdot 0001$.

A

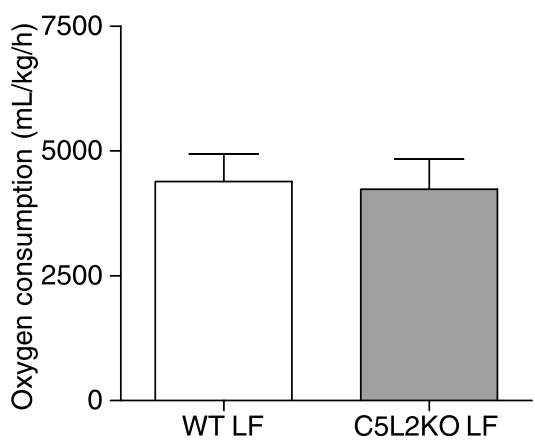

B

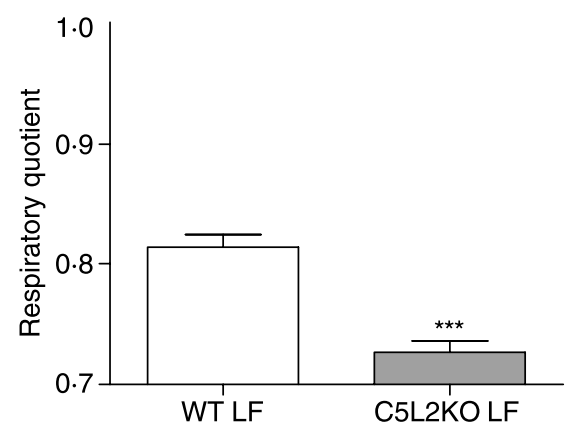

C

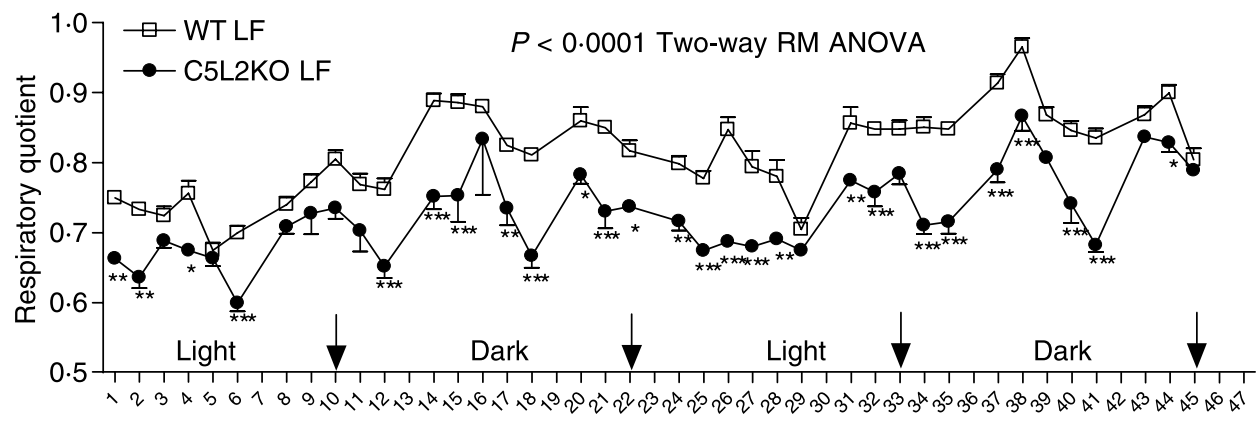

Time (hours)

Figure 6 Indirect calorimetry. Average oxygen consumption (A) and respiratory quotient (B) over a 48-h period for WT LF $n=5$ (white bar) and C5L2KO LF $n=4$ (grey bar) mice. Values are presented as mean \pm S.E.M., where ${ }^{* * *} P<0 \cdot 0001$ assessed by $t$-test. Respiratory quotient over a 48 -h period for WT LF $n=5$ (squares) and C5L2KO LF $n=4$ (circles) mice (C). Statistical differences analyzed by two-way RM ANOVA with Bonferroni post hoc test, where ${ }^{*} P<0 \cdot 05,{ }^{* *} P<0 \cdot 001$ and ${ }^{* * *} P<0 \cdot 0001$. Arrows indicate switch from light to dark phase. 
(Murray et al. 2000). Whereas in the present study there were no differences between $\mathrm{C} 5 \mathrm{~L} 2 \mathrm{KO}$ and WT mouse body weight or adiposity, there was a striking increase in food intake, likely providing a compensatory mechanism to maintain a normal body weight and adiposity in the C5L2KO mice. Nonetheless, there were still alterations in adipose tissue metabolism. Background strain may also contribute to the small differences observed between $\mathrm{C} 3 \mathrm{KO}$ and $\mathrm{C} 5 \mathrm{~L} 2 \mathrm{KO}$ mice. In the present study, the C5L2KO mice were on an obesity-prone $\mathrm{C} 57 \mathrm{Bl} / 6$ background, while the majority of our C3KO mice studies were on a $129 \mathrm{~Sv}$ background (Murray et al. 1999a,b, 2000, Xia et al. 2004).
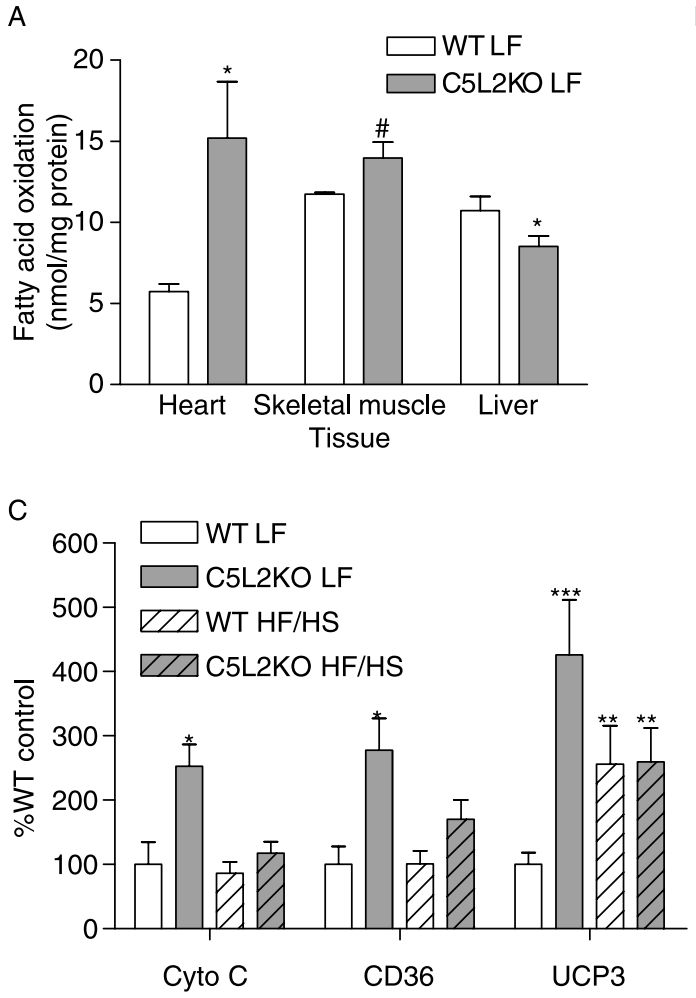

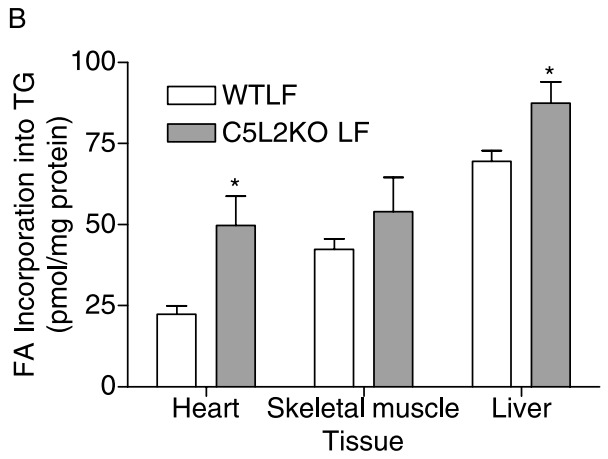

D
E

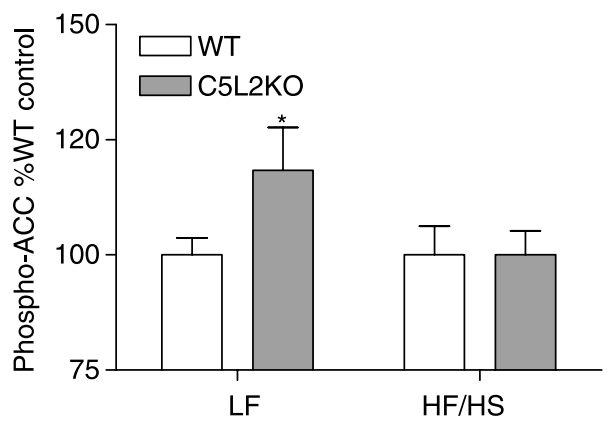

F

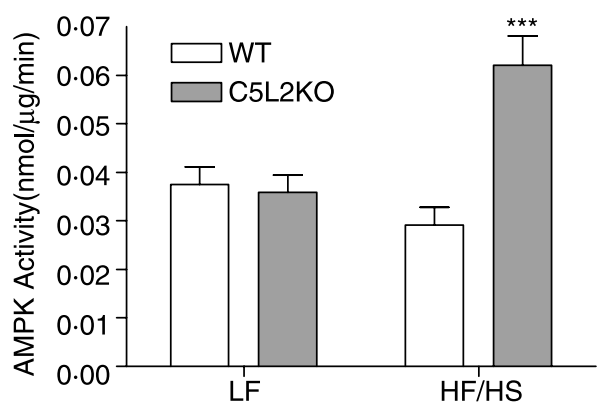

Figure 7 Fatty acid oxidation and skeletal muscle analysis. Tissue palmitate oxidation (nmol/mg protein) (A) and palmitate incorporation into TG (pmol/mg protein) (B) in WT LF $n=9$ (white bars) and C5L2KO LF $n=15$ (grey bars) samples. Skeletal muscle western blot analysis of cytochrome $c$ (Cyto $C$ ), CD36, and uncoupling protein 3 (UCP3) (C). Values are expressed as \% control where WT LF was set as $100 \%$; WT LF $n=4$ (white bars), C5L2KO LF $n=4$ (grey bars), WT HF/HS $n=6$ (white hatched bars), and C5L2KO HF/HS $n=6$ (grey hatched bars). Representative western blots for wild-type (W) and knockout (K) mice (D). Skeletal muscle phospho-ACC levels determined by western blot analysis for WT (white bars) and C5L2KO (grey bars) (E). Values are expressed as \%WT control where WT values were set to $100 \%$ for each LF and HF/HS group. Skeletal muscle AMPK activity ( $\mathrm{nmol} / \mu \mathrm{g}$ protein per $\mathrm{min}$ ) for WT $n=12$ (white bar) and C5L2KO $n=12$ (grey bar) samples (F). Results are presented as mean \pm S.E.M. and statistical differences determined by Wilcoxon Signed Rank test or $t$-test, where ${ }^{*} P<0 \cdot 05,{ }^{* *} P<0 \cdot 001,{ }^{* * *} P<0 \cdot 0001$ and ${ }^{*} P=0 \cdot 056$. 
When 129Sv C3KO mice were compared with C57Bl/6 C3KO mice (review Cianflone et al. 2003), reduced adiposity was still maintained but alterations in lipid clearance were not as prevalent in $\mathrm{C} 57 \mathrm{Bl} / 6 \mathrm{C} 3 \mathrm{KO}$ mice. $\mathrm{C} 57 \mathrm{Bl} / 6 \mathrm{WT}$ mice display differences in cerebral anatomy, food behavior, adiposity, glycemia, and insulin resistance when compared with WT 129Sv mice (Kulkarni et al. 2003), review (Cianflone et al. 2003). Double heterozygous insulin receptor $(-/+)$ and insulin receptor substrate $1(-/+)$ mice on a C57Bl/6 background were severely hyperinsulemic and hyperglycemic, with relatively mild effects in $129 \mathrm{~Sv}$ mice (Kulkarni et al. 2003), leading the authors to conclude the prevalence of diabetes was linked to genetic modifiers. However, in spite of slight differences reported here, the strong similarities between the $\mathrm{C} 3 \mathrm{KO}$ and $\mathrm{C} 5 \mathrm{~L} 2 \mathrm{KO}$ mice phenotypes should be emphasized. On both LF and HF diets, C3KO mice (Murray et al. 1999b) and C5L2KO mice have delayed postprandial dietary TG clearance and hyperphagia with decreased food efficiency (Murray et al. 2000). Finally, $\mathrm{C} 3 \mathrm{KO}$ mice display increased oxidation of both fat and glucose (increased $\mathrm{VO}_{2}$ / constant RQ; Xia et al. 2004), while C5L2KO mice have primarily increased fat oxidation (constant $\mathrm{VO}_{2}$ /decreased RQ). To date, only C5L2 has been shown to act as a receptor involved in ASP-stimulated TGS. These strong parallels in postprandial TG clearance, food intake, and energy expenditure in $\mathrm{C} 3 \mathrm{KO}$ and $\mathrm{C} 5 \mathrm{~L} 2 \mathrm{KO}$ reinforce the connection between ASP and C5L2, since deletion of either the ligand or the receptor results in a similar phenotype.

Physiological alterations in TG storage can be accompanied by compensatory changes in skeletal muscle that may underlie modifications in substrate handling. In the present study, increased in vivo fat oxidation, ex vivo tissue fat oxidation, muscle phospho-ACC and expression of key oxidative proteins (CD36, UCP3, and cytochrome $c$ ) are all evidence of elevated fat utilization in the muscle. Increased phosphoACC levels drive malonyl-CoA production down, thus releasing an inhibition of carnitine palmitoyltransferase 1 , the rate-limiting enzyme for fatty acid oxidation (Ruderman et al. 2003). Together with the increase in cytochrome $c$, which reflects mitochondrial content, and UCP3, which protects mitochondria against lipid-induced oxidative damage under conditions of increased fatty acid flux (Schrauwen et al. 2006), these data confirm increased muscle fatty acid metabolism in C5L2KO mice. Further, the increase in AMPK activity, a cellular indicator of metabolic rate (Ruderman et al. 2003), in the C5L2KO HF/HS mice was striking. Increased AMPK activity suggests that C5L2KO mice augment both fatty acid oxidation and glucose oxidation to compensate for the HF/ HS diet. However, in spite of the adaptation of muscle in C5L2KO mice, the compensation does not appear to be sufficient, and the C5L2KO mice still manifest disturbed insulin metabolism (increased fasting plasma insulin, delayed GTT and decreased insulin stimulation of adipose TGS).

C5L2 is expressed in muscle tissue (Okinaga et al. 2003). ASP inhibits the uptake of lipoprotein lipase derived fatty acids in muscle, although it stimulates this process in adipose tissue (Faraj \& Cianflone 2004). ASP has also been shown to increase glucose transport in myotubes, independently but additively to insulin, through translocation of glucose transporters (GLUT-1, GLUT-3, and GLUT-4) to the cell surface (Maslowska et al. 1997, Tao et al. 1997). We hypothesize that in the absence of C5L2, the effect of ASP on muscle may be removed, contributing to the increase in muscle fat oxidation found in the $\mathrm{C} 5 \mathrm{~L} 2 \mathrm{KO}$ mice. $\mathrm{C} 5 \mathrm{~L} 2 \mathrm{is}$ also expressed in brain and liver (Gao et al. 2005, Kalant et al. 2005) and this may be linked to changes in food intake, RQ, and hepatic lipid metabolism demonstrated here. However, the direct effect of ASP on fat oxidation in muscle, as well as direct effects on brain and liver remains to be evaluated in future studies.

In summary, the overall metabolic profile of $\mathrm{C} 3 \mathrm{KO}$ and C5L2KO mice are comparable, loss of either the ligand or the receptor results in a similar phenotype, reinforcing the physiological role of ASP. Further, the disruption of ASP function leads to alteration in adipose tissue, which is partly compensated by increased fat metabolism in muscle tissue.

\section{Acknowledgements}

This study was supported by a grant from Natural Sciences and Engineering Research Council of Canada (NSERC to KC). K Cianflone holds a Canada Research Chair in Adipose Tissue. P Schrauwen is supported by a fellowship of the Royal Netherlands Academy of Arts and Sciences. M Hesselink is supported by a VIDI grant for innovative research from the Dutch Scientific Organisation (NWO). We appreciate the generosity of Dr Joseph Sorrentino of Regeneron Pharm. Inc. in providing the C5L2 heterozygous mice. The authors declare that there is no conflict of interest that would prejudice the impartiality of this scientific work.

\section{References}

Abu-Elheiga L, Oh WK, Kordari P \& Wakil SJ 2003 Acetyl-CoA carboxylase 2 mutant mice are protected against obesity and diabetes induced by highfat/high-carbohydrate diets. PNAS 100 10207-10212.

Cain SA \& Monk PN 2002 The orphan receptor C5L2 has high affinity binding sites for complement fragments C5a and C5a des-Arg (74). Journal of Biological Chemistry 277 7165-7169.

Cianflone K, Roncari DAK, Maslowska M, Baldo A, Forden J \& Sniderman AD 1994 The adipsin/acylation stimulating protein system in human adipocytes: regulation of triacylglycerol synthesis. Biochemistry 33 9489-9495.

Cianflone K, Maslowska M \& Sniderman AD 1999 Acylation stimulating protein (ASP), an adipocyte autocrine: new directions. Seminars in Cell and Developmental Biology 10 31-41.

Cianflone K, Xia Z \& Chen LY 2003 Critical review of acylation stimulating protein physiology in humans and rodents. Biochimica et Biophysica Acta 1609 127-143.

Claing A, Laporte SA, Caron MG \& Lefkowitz RJ 2002 Endocytosis of G protein-coupled receptors: roles of $G$ protein-coupled receptor kinases and $\beta$-arrestin proteins. Progress in Neurobiology 66 61-79. 
Faraj M \& Cianflone K 2004 Differential regulation of fatty acid trapping in mice adipose tissue and muscle by ASP. American Journal of Physiology. Endocrinology and Metabolism 287 E150-E159.

Festuccia WT, Laplante M, Berthiaume M, Gelinas Y \& Deshaies Y 2006 $\operatorname{PPAR} \gamma$ agonism increases rat adipose tissue lipolysis, expression of glyceride lipases, and the response of lipolysis to hormonal control. Diabetologia 49 2427-2436.

Gao H, Neff TA, Guo RF, Speyer CL, Sarma JV, Tomlins S, Man Y, Riedemann NC, Hoesel LM, Younkin E et al. 2005 Evidence for a functional role of the second C5a receptor C5L2. FASEB Journal 19 1003-1005.

Gerard NP, Lu B, Liu P, Craig S, Fujiwara Y, Okinaga S \& Gerard C 2005 An anti-inflammatory function for the complement anaphylatoxin C5a binding protein, C5L2. Journal of Biological Chemistry 280 39677-39680.

van Harmelen V, Reynisdottir S, Cianflone K, Degerman E, Hoffstedt J, Nilsell K, Sniderman A \& Arner P 1999 Mechanisms involved in the regulation of free fatty acid release from isolated human fat cells by acylation-stimulating protein and insulin. Journal of Biological Chemistry 274 18243-18251.

Ibrahimi A, Bonen A, Blinn WD, Li X, Zhong K, Cameron R \& Abumrad NA 1999 Muscle-specific overexpression of FAT/CD36 enhances fatty acid oxidation by contracting muscle, reduces plasma triglycerides and fatty acids, and increases plasma glucose and insulin. Journal of Biological Chemistry 274 26761-26766.

Kalant D, Cain SA, Maslowska M, Sniderman AD, Cianflone K \& Monk PN 2003 The chemoattractant receptor-like protein C5L2 binds the C3a desArg77/acylation-stimulating protein. Journal of Biological Chemistry 278 11123-11129.

Kalant D, Maclaren R, Cui W, Samanta R, Monk PN, Laporte SA \& Cianflone K 2005 C5L2 is a functional receptor for acylation stimulating protein. Journal of Biological Chemistry 280 23936-23944.

Kulkarni RN, Almind K, Goren HJ, Winnay JN, Ueki K, Okada T \& Kahn CR 2003 Impact of genetic background on development of hyperinsu-

linemia and diabetes in insulin receptor/insulin receptor substrate-1 double heterozygous mice. Diabetes 52 1528-1534.

Maslowska M, Sniderman AD, Germinario R \& Cianflone K 1997 ASP stimulates glucose transport in cultured human adipocytes. International Journal of Obesity and Related Metabolic Disorders 21 261-266.

Murray I, Sniderman AD \& Cianflone K 1999a Enhanced triglyceride clearance with intraperitoneal human acylation stimulating protein (ASP) in C57Bl/6 mice. American Journal of Physiology. Endocrinology and Metabolism 277 E474-E480.

Murray I, Sniderman AD \& Cianflone K 19996 Mice lacking acylation stimulating protein (ASP) have delayed postprandial triglyceride clearance. Journal of Lipid Research 40 1671-1676.

Murray I, Havel PJ, Sniderman AD \& Cianflone K 2000 Reduced body weight, adipose tissue, and leptin levels despite increased energy intake in female mice lacking acylation-stimulating protein. Endocrinology 141 1041-1049.

Neri BP \& Frings CS 1973 Improved method for determination of triglycerides in serum. Clinical Biochemistry 19 1201-1202.

Ohno M, Hirata T, Enomoto M, Araki T, Ishimaru H \& Takahashi TA 2000 A putative chemoattractant receptor, $\mathrm{C} 5 \mathrm{~L} 2$, is expressed in granulocyte and immature dendritic cells, but not in mature dendritic cells. Molecular Immunology 37 407-412.
Okinaga S, Slattery D, Humbles A, Zsengeller Z, Morteau O, Kinrade MB, Brodbeck RM, Krause JE, Choe HR, Gerard NP et al. 2003 C5L2, a nonsignaling C5A binding protein. Biochemistry 42 9406-9415.

Pekna M, Hietala MA, Rosklint T, Betsholtz C \& Pekny M 1998 Targeted disruption of the murine gene coding for the third complement component (C3). Scandinavian Journal of Immunology 47 25-29.

Persson L, Boren J, Robertson AK, Wallenius V, Hansson GK \& Pekna M 2004 Lack of complement factor C3, but not factor B, increases hyperlipidemia and atherosclerosis in apolipoprotein $\mathrm{E}-/$ - low-density lipoprotein receptor $-/-$ mice. Arteriosclerosis, Thrombosis, and Vascular Biology 24 1062-1067.

Ruderman NB, Saha AK \& Kraegen EW 2003 Minireview: Malonyl CoA, AMP-activated protein kinase, and adiposity. Endocrinology 144 5166-5171.

Sambandam N, Steinmetz M, Chu A, Altarejos JY, Dyck JR \& Lopaschuk GD 2004 Malonyl-CoA decarboxylase (MCD) is differentially regulated in subcellular compartments by $5^{\prime} \mathrm{AMP}$-activated protein kinase (AMPK). Studies using $\mathrm{H} 9 \mathrm{c} 2$ cells overexpressing MCD and AMPK by adenoviral gene transfer technique. European Journal of Biochemistry 271 2831-2840.

Schrauwen P, Hoeks J \& Hesselink MKC 2006 Putative function and physiological relevance of the mitochondrial uncoupling protein-3: involvement in fatty acid metabolism? Progress in Lipid Research 45 17-41.

Tao Y, Cianflone K, Sniderman AD, Colby-Germinario SP \& Germinario RJ 1997 Acylation-stimulating protein (ASP) regulates glucose transport in the rat L6 muscle cell line. Biochimica et Biophysica Acta 1344 221-229.

Valenzuela DM, Murphy AJ, Frendewey D, Gale NW \& Economides AN 2003 High-throughput engineering of the mouse genome coupled with high-resolution expression analysis. Nature Biotechnology 21 652-659.

Walsh MJ, Sniderman AD, Cianflone K, Vu H, Rodriguez MA \& Forse RA 1989 The effect of ASP on the adipocyte of the morbidly obese. Journal of Surgical Research 46 470-473.

Wetsel RA, Kildsgaard J, Zsigmond E, Liao W \& Chan L 1999 Genetic deficiency of acylation stimulating protein (ASP/C3adesArg) does not cause hyperapobetalipoproteinemia in mice. Journal of Biological Chemistry 274 19429-19433.

Xia Z, Sniderman AD \& Cianflone K 2002 Acylation-stimulating protein (ASP) deficiency induces obesity resistance and increased energy expenditure in ob/ob mice. Journal of Biological Chemistry 277 45874-45879.

Xia Z, Stanhope KL, Digitale E, Simion O-M, Chen LY, Havel PJ \& Cianflone K 2004 ASP deficiency results in increased energy expenditure in mice. Journal of Biological Chemistry 279 4051-4057.

Yasruel Z, Cianflone K, Sniderman AD, Rosenbloom M, Walsh M \& Rodriguez MA 1991 Effect of acylation stimulating protein on the triacylglycerol synthetic pathway of human adipose tissue. Lipids $\mathbf{2 6}$ 495-499.

\section{Received in final form 24 April 2007 \\ Accepted 10 May 2007 \\ Made available online as an Accepted Preprint 15 May 2007}

